\title{
CHAPTER SIX \\ The Scope for Wisdom: Early Buddhism on Reasons and Persons
}

\author{
JAKE H. DAVIS
}

To this extent, Ānanda, one is born and ages and dies and passes away and takes birth again. To this extent there is a path for designations, a path for expressions, a path for concepts. To this extent there is scope for wisdom. To this extent the cycle continues for being here to be conceived. That is, to the extent that name-and-form together with consciousness continue through dependence on one another. (Mahānidāna Sutta, DN II 63-64) ${ }^{1}$

\section{INTRODUCTION}

The denial that persons exist, in some ultimate sense, is widely understood to be a central Buddhist doctrine. In Consequences of Compassion, Charles Goodman (2009) suggests that in a range of classical Buddhist sources some version of this metaphysical thesis about persons helps to underwrite an ethical thesis, that we ought to minimize the total amount of suffering there is in the world. There is a compelling connection between these two ideas: since we all agree that our own suffering is to be avoided, if there are ultimately no distinctions between persons, then perhaps one ought to act or live in whatever way will most effectively reduce all of the suffering there is in the world, regardless of whose it is. Nonetheless, as a characterization of early Buddhist thought this proposal is doubly mistaken. The Buddha, as he is portrayed in the early Buddhist discourses, endorses neither the metaphysical claim, that persons on some ultimate level do not exist, nor the ethical claim, that we ought to live in whatever way will minimize the total amount of suffering there is in the world. Instead, early Buddhism has a different, and more novel, contribution to make to contemporary ethical thought. Or so I will argue. ${ }^{2}$

Damien Keown, in his seminal work The Nature of Buddhist Ethics (1992), argues that Buddhist ethics cannot be understood within a Consequentialist framework, one that bases ethical claims about how we ought to live on considerations about the consequences for aggregate happiness or suffering in the 
world. Keown suggests instead that Buddhist ethics has more in common with the teleological approach to Virtue Ethics characteristic of Aristotle's ethical thought. While I will also point out in passing some problems with Keown's Aristotelian interpretation, Goodman offers a much more extensive argument against Keown's reading. It is difficult to find decisive evidence either for a teleological or for a Consequentialist reading, however, for at least two reasons. First, the structural similarities between the two approaches can make them seem indistinguishable in practice; Goodman highlights the especially close similarities between Aristotelian versions of Virtue Ethics and a theory that focuses on the consequences for aggregate welfare of having certain character traits (2009: 41ff.). Second, in part because the Buddhist sources are mainly focused on practical ethical questions rather than on ethical theory, they are relatively amenable to multiple different lines of theoretical interpretation.

One strategy Goodman employs to tip the balance in favor of his Consequentialist reading is to appeal to a connection between reductionism about persons and Consequentialism in ethics that has been brought to light by Derek Parfit in his influential Reasons and Persons. Goodman suggests that just such a connection is present, at least implicitly, in a range of classical Buddhist sources. Parfit, in turn, explicitly claims that "Buddha would have agreed" with his reductionist view about persons (1984: 273, emphasis in original).

Both Parfit and Goodman suggest that the reductionist view about persons helps to lend credence to ethically demanding Welfare-Consequentialist ethical theories, approaches that determine whether an action is right by appealing to its consequences for total happiness or suffering in the world. This approach suggests an important connection between two central aspects of Buddhist thought: the universal characteristic of nonself (Pāli anattā) and the nature of what is ethically wholesome (Pāli kusala). And this, in turn, suggests one way in which Buddhist meditation could lead to ethical insight. A common theme across contemporary Buddhist traditions is the suggestion that meditation practices offer a means for individuals to realize the metaphysical truth that there is no self. Perhaps Buddhist meditation offers access, of a kind that has been relatively absent from Western thought, to the grounds for believing that we ought to act so as to minimize suffering for all beings. If so, this would be an important contribution to contemporary ethical thought and practice.

While there is a kernel of truth in this suggestion, I think that the distinctive contribution of Buddhist approaches to ethics lies elsewhere. In a discourse in the Samyutta Nikāya (SN), the Buddha says, "It is in just this fathom-long carcass with perception and mind that I make known the world, the cause of the world, the cessation of the world, and the path leading to the cessation of the world" (SN I 144). Commenting on this discourse, Bhikkhu Bodhi explains:

The world with which the Buddha's teaching is principally concerned is "the world of experience," and even the objective world is of interest only to the extent that it serves as the necessary external condition for experience. (Bodhi 2000: 394) 
This is not to say that the Buddha's ethical teachings are not concerned with the effects of one's actions on other persons in the external world; as we will see, they are. However, I will suggest that early Buddhist ethics is concerned with the external consequences of one's actions in virtue of the fact that one ought to have the sort of motivations that would make us concerned about such things. And this is a fact that each of us can experience for ourselves. It is something that one can know and see from within, and only from within, one's world of experience.

The line of thought that I draw out from the early Buddhist discourses does not ground its claims, metaphysical or ethical, in a perspective that abstracts away from one's particular experience of the world in order to adopt the sort of objectivity that Thomas Nagel (1986) calls "the view from nowhere." On the contrary, the suggestion is instead to inhabit more fully one's own subjective experience of the world. The point is to watch how experience comes to be and how it ceases to be see, so as to see and know the nature of experience and the conditions under which one comes to have experience of the world at all. Indeed, this is an ethical claim: the characterization of the world of experience, its cause, its cessation, and the path to its cessation that is given in the Samyutta passage above is a variant of the four noble truths; thus the unsatisfactoriness $(d u k k h a)$ inherent in the world of experience is to be comprehended (pariññeyya), its cause is to be abandoned (pahätabbam), its cessation is to be directly experienced (sacchikatabbam), and the path to that cessation is to be cultivated (bhāvetabbam) (as at SN V 422).

Two recent evaluations of the early Buddhist doctrine of anatta (nonself) by Sue Hamilton (2000) and Alexander Wynne (2010) appeal centrally to this emphasis on understanding the conditional nature of the world of experience. Both authors argue that the kind of reductionism about persons appealed to by Goodman, while very much present in later developments of Buddhist thought, nonetheless stands in opposition to a more subtle and profound approach to persons and subjectivity found in earlier layers of Buddhist thought. These historical claims, and the methodologies employed by Hamilton and Wynne, are not without controversy. For one, the arguments of both Hamilton and Wynne are based primarily on the Pâli Nikāyas. This body of texts has been preserved in the Theravāda Buddhist traditions of Southeast Asia, with only minor variations between different recensions. Though the Nikāyas have often been assumed by Western scholars to be the earliest and most authoritative record available of what the historical Buddha taught, this is problematic as a general assumption. For one, research into parallel versions of the early Buddhist discourses translated in the Chinese Âgamas as well as in Tibetan versions and some Sanskrit fragments has suggested a means of identifying earlier and later elements of crucial discourses. This approach is important because it offers a means for historical analysis that specifically does not privilege the Theravāda tradition as having preserved in all cases the earliest or most authoritative version of a teaching (Anālayo 2011, 2012a). Nonetheless, the emphasis on the world of experience that Bodhi, Hamilton, Wynne, and others find evident in the Pāli Nikāyas, as an independent philosophical proposal, has novel and important contributions to make to contemporary ethical theory (Davis 2014). Moreover, 
the implications of this emphasis on subjective experience for understanding the structure of ethical thought within the Pāli Nikāyas are largely yet to be drawn out. Finally, these implications may well apply to understanding the structure of early Buddhist ethics more generally, if further comparative research offers evidence from other recensions of the early Buddhist discourses for a similar approach to the world of experience and to the doctrine of nonself in particular.

I cannot attempt here a comprehensive survey of scholarship on Buddhist ethics, or even that focused on the early Buddhist discourses. ${ }^{3}$ Instead, my aim here is to bring out one distinctive and philosophically promising aspect of the approach to ethics found in these texts. In Section Two I survey some evidence for the nature of ethical reasoning in early Buddhist thought. Section Three turns to the nature of persons, developing an approach to understanding nonself as a characteristic of one's subjective experience of the world. Section Four extends this same approach to understand the nature of objectivity in early Buddhist ethics. Briefly sketching an account that I have defended in more detail elsewhere (Davis 2014), I propose that the connection drawn between mindfulness and wisdom in the early Buddhist discourses offers a distinctive and promising approach to grounding ethical claims.

\section{ETHICAL REASONING IN EARLY BUDDHISM}

In the well-known discourse to the Kālāmas, the Buddha rejects certain kinds of epistemic principles in ethics. He advises the Kālāmas not to rely only on the authority of a tradition or hearsay or texts or a teacher, and also not to rely only on the basis of logical reasoning or inference or probability or acceptance of a view. The Buddha's positive advice begins as follows:

When you know for yourselves "these qualities (dhammā) are unwholesome (akusala $)$, these qualities are blameworthy (sāvaij $\bar{a})$, these qualities are criticized by the wise (viñ nugarahitā), these qualities when taken on and adopted lead to harm and suffering (ahitāya dukhāya), then you should abandon them (pajaheyyātha)

..." When you know for yourselves "these qualities are wholesome (kusalā), these qualities are blameless (anavajja) , these qualities are praised by the wise (viñ ñuppasatthā), these qualities when taken on and adopted lead to welfare and happiness (bitāya sukhāya), then you should enter and remain in them (upasampajia vihareyyātha)." (AN I 189-190)

Both in the case of the unwholesome and in the case of the qualities (dhammā) he characterizes as ethically unwholesome, and also in the case of the qualities that he characterizes as ethically wholesome, immediately after giving this advice, the Buddha runs through some examples. The Kālāmas agree that when greed (lobha), hatred (dosa), or delusion (moha) arise inside a person, they lead to harm and suffering. The Buddha points out that someone overcome by such qualities violates the ethical principles known in Buddhism as the five precepts, that is, he kills, steals, commits adultery, lies, and encourages others to do those things, 
all of which is for long-term harm and suffering. When the opposites of these qualities arise in a person, he does not kill, steal, commit adultery, lie, or encourage others to do those things, all of which is for long-term welfare and happiness. ${ }^{4}$ Having thought through such consequences for suffering and happiness, the Kālāmas become clear as to which of these qualities of heart are unwholesome, blameworthy, criticized by the wise, leading to harm and suffering, and which of these qualities of heart are wholesome, praiseworthy, praised by the wise, leading to welfare and happiness.

For our purposes here there are two especially notable features of this passage. For Western philosophers, it will be notable that the focus in this discussion about what is praiseworthy and what blameworthy is not focused in the first case on the evaluation of actions, nor the evaluation of long-term character traits. It does take motivational states, including what might be called a goodwill, as the central focus for the purpose of evaluating praise- and blame-worthiness. But the early Buddhist approach is not then to evaluate the goodness of a goodwill in terms of its conformance with rational principles such as universalizability. In short, the proposal offered here for how to go about evaluating praise- and blame-worthiness is distinct from any of the major theories of Western ethics, a point that makes it worthy of notice by philosophers used to operating mainly with those paradigms. As Goodman notes, "The Buddhist technical terms we might be inclined to translate as 'virtuous' (such as Pāli kusala, Skt. kuśala, Tib. dge ba) are, in the first instance, applied to occurrent mental states" (2009: 195). The foundational focus, in this discourse with the Kālāmas, and more generally in the early Buddhist discourses, is on greed (lobha), hatred (dosa), delusion (moha), and their opposites. Elsewhere, I have called such states "qualities of heart" (Davis 2014). Among all the possible states $($ dhamma $)$ a person might experience, it is these occurrent emotional, conative, and cognitive states that the early Buddhist texts take as the foundational focus of ethical discussion. ${ }^{5}$

In one well-known line from the Anguttara Nikāya (AN), the Buddha says, "It is cetana (intention or motivation) that I call kamma" (AN III 415). Scholars such as Richard Gombrich (2006: 51) have argued that in the broader Indian context this suggestion was revolutionary, turning the notion of morally valenced action inward, focusing ethics on one's psychological states rather than the consequences of one's outer actions. This emphasis on internal motivations suggests to Keown that Buddhist ethics cannot be Consequentialist:

It is the preceding motivation (cetana $\bar{a}$ ) that determines the moral quality of the act and not its consequences. In Buddhism acts have bad consequences because they are bad acts-they are not bad acts because they have bad consequences. (Keown 1992: 178)

Keown offers an extended comparison of cetanā with Aristotle's conception of prohairesis, and sees a broader parallel as well between the structure of Buddhist and Aristotelian approaches to ethics. He points, for instance, to another passage from the Aniguttara Nikāya where wholesome conduct (kusala silla) is said ultimately to 
have knowledge and vision of release as its purpose (attha) and benefit (anisamsa) (AN V 2). The discourse immediately following describes this as a natural process, saying that for someone with wholesome conduct there is no need to form the intention $(\operatorname{cetan} \bar{a})$ for freedom from regret to arise. Likewise for each progressive stage in the series,

For one with freedom from regret ... joy ... tranquility ... ease ... concentration ... knowledge and vision of things as they are ... disenchantment ... dispassion ... there is no need to form the intention "may I realize knowledge and vision of release." It is just the nature of things (dhammatā) that one disenchanted and dispassionate will realize knowledge and vision of release ... Thus, bhikkhus, one state flows into the next state, one state fills up the next state for the sake of going from the near shore to the far shore. (AN V 2-4)

Just as Aristotelian ethics is grounded in a particular notion of flourishing (eudaimonia), Keown argues, so too Buddhist thought grounds ethical valence in the goal of nibbāna. He takes both these systems to be teleological in the sense of providing a "framework for personal cultivation and accomplishment ... structured in accordance with a specific connection of human nature and its telos" (Keown 1992: 203). Since in this Anguttara discourse wholesome conduct is said to have nibbāna as its ultimate purpose and benefit, one might take Keown's (1992) proposal to be that the reason intentions motivated by states such as compassion are worthy of cultivation is just that such states (and not others) are conducive to realizing nibbanna. If this is the reading that Keown is proposing, however, it goes beyond what is found in the discourses themselves.

Recall that in the discourse to the Kālāmas, having made wholesome and unwholesome qualities of heart the focus of ethical evaluation, the Buddha does not appeal to considerations about which of these qualities are conducive to nibbāna, but rather gives examples that distinguish between wholesome and unwholesome qualities by appealing to their consequences for welfare. This is a second notable feature of the approach to ethical reasoning on display in the discourse to the Kâlāmas precisely whose welfare is to be taken into account. However, in a discourse in the Majjhima Nikāya, it is made explicit that one should consider both one's own welfare and that of others. In that discourse, the Buddha starts up a conversation with his young son Rāhula on the subject of telling lies in jest; it seems that according to multiple commentarial traditions Rāhula was prone to just this vice (Anālayo 2011: 342). "For one who feels no shame in telling a deliberate lie," the Buddha says, "there is no evil he would not do. Therefore, one should train oneself thus: I will not lie even in jest" (MN I 415). Presumably as a way of elaborating and generalizing the point, the Buddha suggests that one ought to reflect before, during, and after actions of body, speech, and mind:

Did this action of body ... speech ... mind lead to my own affliction, to the affliction of others, to the affliction of both, was it an unwholesome action 
of body ... speech ... mind, resulting in suffering, bearing fruit in suffering? (MN I 415)

When a monastic knows on reflection that his action was unwholesome, with unhappy results, he ought to confess it and refrain in the future. When he knows that his action was wholesome with happy results, he ought to joyously continue to train himself in wholesome qualities.

It is interesting philosophically that the appeal to consequences here comes as an elaboration on the point that one ought never to lie. Act-Consequentialist approaches will typically deliver the result that one ought to lie under circumstances where that act of lying would lead to overall benefit. However, this is not the case for Consequentialist approaches that take rules as the primary focus of ethical evaluation. Although Keown ultimately rejects the hypothesis that Buddhist ethics is Consequentialist, he concedes that among Consequentialist theories a form of negative rule Consequentialism would be the "closest approximation" (1992: 230). The general idea of such an approach would be that Buddhist ethics applies the precepts against killing, stealing, lying, and so on inflexibly, and that these rules are, in turn, justified in virtue of the fact that these are the rules that, when followed inflexibly, result in an overall reduction in suffering (Keown 1992: 177). Goodman takes up the proposal that Keown ultimately rejects, and argues for a RuleConsequentialist interpretation of early Buddhism and/or the modern Theravādait is not quite clear which, since neither Keown nor Goodman distinguishes carefully between the two.

I doubt that Rule-Consequentialism is the correct characterization either of early Buddhist ethics or of how modern Theravāda Buddhists reason. In both cases, my suggestion is that the central thrust of these approaches is instead to take occurrent states of mind as the primary unit of ethical evaluation. The analysis of mercy killings offered in the Theravāda Abhidhamma and commentaries makes clear that the reason such killings are wrong is that even in such cases it is not psychologically possible for a person to intentionally take life unless the state of dosa (hatred or aversion) has arisen in the agent's mind (Gethin 2004). Rupert Gethin notes here the commentary's suggestion that the painful, unwholesome states that actually motivate intentional killing are not easy for those who are not wise to notice (dujjānam etam puthujjaneh $\vec{\imath}$ ), because these states are fleeting and occur close in time to wholesome states such as compassion; this traditional analysis is repeated by modern Theravāda teachers both in Thailand and in Burma. ${ }^{6}$

We have seen that the Buddha's advice to the Kālāmas similarly focuses on qualities (dhammā) such as greed (loba), hatred (dosa), and delusion (moha), as well as their opposites. On an approach that takes qualities of heart as the central focus of ethical evaluation in this way, conclusions about which actions are wholesome and unwholesome that follow from this may well vary widely depending on particular circumstances. Certain kinds of actions, those that cannot be performed without involving unwholesome states, may never be wholesome. However, since the ethically charged situations we find ourselves in are complex, it is not always 
clear ahead of time what a person motivated by wholesome qualities of heart would do. This helps to accommodate the sense that Buddhist ethics is "Particularist," as Charles Hallisey (1996) puts it. ${ }^{7}$ The idea here, echoed by other recent interpreters (Heim 2014; Garfield in press) is that Buddhist ethical texts are not in the business of offering a general system from which to derive decision procedures for how to act or how to be. Rather, the right thing to do will vary in ways that are not codifiable-in some cases even breaking the precepts may be the virtuous thing to do, and Buddhist ethical texts are instead in the business of inculcating the right sorts of emotional responses to the complex situations that human beings have to navigate.

One might wish to insist that even about emotional responses, the Buddhist ethical texts offer no principled general means of determining which are to be to be cultivated and which are to be abandoned. One aim of this chapter is to argue that such a wholesale Particularist reading would be mistaken. The kind of context sensitivity about right action that is rightly recognized by interpreters such as Hallisey can follow even from an ethical theory that offers a different, principled foundation. By generalizing the structure of the Kālāma Sutta, for instance, a Welfare-Consequentialist theory could take emotional responses as the primary focus of ethical evaluation, rather than acts or rules or character traits. ${ }^{8}$ On this approach, if greed or hatred or delusion as a type of occurrent mental state leads in general to maximizing the total suffering in the world, then when it arises internally in us, we ought to abandon it and not act out of it. Likewise, if their opposites typically lead to minimizing the total suffering in the world, then when such qualities of heart arises internally in us, we ought to cultivate them in our thoughts, speech, and actions. This "Quality-Consequentialism" can, I think, offer a close approximation of early Buddhist ethical conclusions. Though I suggest in Section Four how it fails to get right the structure of early Buddhist ethics at a more foundational level, it nonetheless would offer justification for many of the same ethical claims to which early Buddhist thought is committed.

Perhaps the strongest evidence for thinking the foundational structure of early Buddhist ethics is Consequentialist comes from the Bähitika Sutta and its parallel in the Chinese Madhyama-ägama. In this discourse, the Venerable Ānanda answers a series of questions asked by King Pesanadi:

Now, Venerable Ānanda, what kind of bodily behaviour is censured by wise recluses and Brahmins? Any bodily behaviour that is unwholesome, great king ... what kind of bodily behaviour is unwholesome? Any bodily behaviour that is blameworthy ... what kind of bodily behaviour is blameworthy? Any bodily behaviour that brings affliction ... what kind of bodily behaviour brings affliction? Any bodily behaviour that brings that has painful results ... Now, Venerable Ānanda, what kind of bodily behaviour has painful results? Any bodily behaviour, great king, that leads to one's own affliction, or to the affliction of others, or to the affliction of both, and on account of which unwholesome states increase and wholesome states diminish. Such bodily behaviour is censured by wise recluses and Brahmins, great king. (MN II 114) 
In the parallel to this discourse preserved in the Chinese Madhyama-ägama, Annanda describes the behavior that "the wise detest" as actions that harm oneself and others and both, that "destroy wisdom and foster evil," and that does not lead to awakening and nibbāna (Anālayo 2007: 159ff.). He goes on to say that those who undertake such conduct "do not know according to reality" what things should and should not be eliminated, what things should and should not be accomplished. $\mathrm{He}$ concludes that because of this ignorance, "wholesome things decrease and unwholesome things increase."

The discussions with the Kālāmas and with Rāhula above point to consequences for welfare as ethically relevant. Not only do both the Pâli and Chinese versions of the Bähitika Sutta repeat this point, but the structure of the discourse also lends further support to a Consequentialist interpretation. Quoting the Pāli version, Goodman (2009: 62) points out that "it is natural to interpret the passage as defining the earlier expressions successively in terms of the later ones," as giving successively more foundational accounts of what it is for a behavior to be something one ought not to do. ${ }^{9}$ On this reading of the Pāli version, Ānanda is saying that what makes it the case that certain bodily behaviors are unwholesome is the fact that those behaviors are blameworthy; what makes it the case those bodily behaviors are blameworthy is that they bring affliction; what makes it the case that those bodily behaviors bring affliction is that they have painful results. The final stage of this series of definitions proposes that what makes it the case those bodily behaviors have painful results is the fact they that have negative consequences for the agent's welfare and the welfare of others, but also the fact that such behaviors increase unwholesome states and diminish wholesome states, and (in the Madhyama-ägama version) that such behaviors are not conducive to realizing nibbāna.

Maximizing Consequentialist theories define what is right as what maximizes the good. The good can then be defined in various ways, yielding different forms of Consequentialism. An objective list theory of the good simply gives a list of the goods there are, denying that further noncircular explanation can be offered for why these are the goods to maximize. Goodman suggests that the Pāli version of the Bāhitika Sutta might articulate just this sort of structure:

The series of definitions terminates with reference to two aspects of the consequences of the action: its tendency to promote "affliction", that is, painful feelings, and its tendency to cause bad states of character to increase and good ones to diminish. If this final formulation represents the most fundamental account of what makes an action wrong, then the moral theory of the Bähitika Sutta is a consequentialist theory with a two-part objective list theory of the good. (Goodman 2009: 62)

Earlier in his book, Goodman (2009: 41) describes a "universalist consequentialism based on an objective list theory, such that the list of intrinsic goods includes character traits," and identifies this with what Thomas Hurka calls "Perfectionist Consequentialism." Goodman argues that despite their similarities, perfectionist 
Consequentialism can be distinguished from Aristotelian Virtue Ethics. His central suggestion is that whereas Virtue Theories are agent-relative, Consequentialist theories are agent-neutral.

This agent-neutrality leads Consequentialist theories to be radically revisionary and make ethical demands on us far beyond the demands made by most conventional moral systems. According to a Virtue Theoretic approach, an agent ought to do what cultivates her own virtuous character traits. In contrast, perfectionist Consequentialism will hold that an agent ought to do whatever maximizes virtue for all beings, even if it were to decrease her own virtuous character traits. "That means that a character Consequentialist would be willing to make himself worse in order to make others better, so long as the total amount of virtue in the universe increased" (Goodman 2009: 43). Likewise, a Welfare-Consequentialist approach that focused on actions, instead of character traits, may suggest that those of us living in wealthy countries ought to be willing to reduce our wealth and well-being dramatically in order to save the lives of people we have never met. Peter Singer (1972) famously argues that if it would be wrong to let a child drown in front of us to save our expensive shoes from getting ruined, it is equally wrong to allow a child to die from preventable diseases when we could save her by giving up an amount of wealth comparable to (or less than) the costs of an expensive pair of shoes. And there are many such children. The crux this argument turns on an agent-neutral conception of value: the lives of those distant from us have no less value than the lives of those we come into contact with.

Goodman refers to Parfit in tying the high ethical demands required by Consequentialist approaches directly to a reductionist metaphysics of persons:

Because of its commitment to agent-neutrality, consequentialism regards the divisions between the lives of different individuals as no more significant than the differences between different periods of a particular individual's life. Actions that benefit the agent, or the agent's family and friends, at the expense of beings in general are just as irrational as actions that benefit me in the short run but do much greater harm to my long-term interests. (Goodman 2009: 44)

Goodman suggests that in order to test whether a Virtue Theoretic or a Consequentialist framework can be attributed to a particular school of Buddhist thought we can look for "characteristics that are distinctive to, or at least indicative of, Consequentialism, such as agent-neutrality, extreme demands, injunctions to promote the welfare of others, and the ability to draw support from critiques of personal identity" (2009: 45). The last of these would seem low-hanging fruit. After all, the Buddhist tradition is full of metaphysical critiques of personal identity. Moreover, the other considerations may be more equivocal.

We have seen that the ethical reasoning evident in the early Buddhist texts does emphasize consequences as an important factor. And I have suggested that one can construct a Consequentialist account focused on the evaluation of types of occurrent mental states that would approximate many of the ethical claims made in the early Buddhist discourses. However, many of the instances that we have seen 
so far of early Buddhist ethical reasoning could also be interpreted along virtuetheoretical lines. This is so in part because the formal feature of Consequentialism, the maximization of the total good in the external world as determining what is right, is not evident in the texts. Even if a maximizing procedure were evident, moreover, we might agree that one ought to do what one thinks will maximize welfare for oneself and for others, but suggest that one ought to act in this way just in virtue of the fact that that is what a compassionate person would do. For instance, the Vinaya texts portray the Buddha as laying down rules not only in order to decrease unwholesome mental states and increase wholesome ones in individual monastics, but also for the good of the whole monastic community, for the sake of nurturing the public's faith in the teachings, and for the sustaining of the teachings and the discipline (as at Vin. III 21). Since these texts are arguably one of the primary sources for understanding early Buddhist ethics, one might take this as evidence that early Buddhist ethics does not evaluate acts solely on the basis of the qualities of heart they involve. However, we can equally wonder why it is the case that one ought to be motivated to lay down rules that serve the welfare of the many in this way. And here, a plausible answer is that one ought to be motivated in such a way because that is just what a compassionate person would do. On such an approach, claims about which character traits or mental states are wholesome would again serve as the foundational justification for which acts and rules are wholesome. One could offer a similar Virtue Theoretic basis for some extreme ethical demands. Thus it might be that someone who has the trait of being contented with little, or the state of non-greed, would be motivated naturally to give up much of their wealth so as to better serve others; we might see Buddhist monasticism as one example of this.

I return to these points below. For now, it is enough to note that it is not easy to distinguish a Virtue Theoretic approach from a perfectionist Consequentialist approach on grounds such as extreme demands and injunctions to promote welfare. However, Goodman suggests that the different "metaphysical bases" supporting the two theories can help here. It is possible to combine reductionism about persons with a Virtue Ethics. Nonetheless, Parfit's reductionism about persons offers argumentative support for Consequentialism. And, on the other hand, Aristotle's ethics is grounded in his philosophical biology, in particular its conception of human beings as having a natural function. Goodman suggests, then, that if we find in Buddhism a claim that persons can be reduced to psychophysical processes and do not have an essential nature that can be appealed to as the ground of ethics, this should be taken as indirect evidence in favor of a Consequentialist reading of Buddhist ethics.

\section{THE CHARACTERISTIC OF NONSELF}

The Discourse on the Characteristic of Nonself, the Anatta-lakkhana Sutta, presents the Buddha telling his audience in no uncertain terms that physical form, feeling, perception, conditioned volitions, and consciousness itself are not to be regarded as 
self. These five are the khandhas, often interpreted as "aggregates" (but see note 9). The discourse presents the same injunction in regard to each of the five, beginning with physical form. "Any physical form whatever, past, present or future, internal or external, gross or subtle, base or refined, far or near, is to be viewed as it is with right understanding, "this is not mine, I am not this, this is not myself"' (SN III 66). The discourse goes on to say that viewing physical form, feeling, perception, conditioned volitions, and consciousness in this way leads to the goal of release from suffering.

Many later Buddhist expositions have understood this central teaching as a claim that in some ultimate sense persons do not exist. Thus in the Questions of Milinda, the Elder Buddhist monk Nāgasena explains that although he is known as "Nāgasena," this is just a concept, "In the ultimate sense there is no person to be found here" (Miln. 28). Parfit (1984: 273, 502) cites this line from Nāgasena as evidence that the Buddha would agree with the reductionist view. Nāgasena, in turn, cites as support a poem attributed to the nun Vajirā, found in the Samyutta Nikāya:

Just as, with an assemblage of parts, The word "chariot" is used, So, when the aggregates are present, There's the convention "a being."

It's only suffering that comes to be, Suffering that stands and falls away. Nothing but suffering comes to be, Nothing but suffering ceases. (SN I 135 in Bodhi 2000: 230)

Nāgasena explicates Vajirā's chariot analogy by distinguishing between the concept (pañ natti) of a person and what is "found" in the ultimate sense (paramattho). There are various parts of a chariot: the pole, the axle, the wheels, the body, and so on. Dependent on the pole, and the axle, and the wheels, and the body and so on, there is the concept СНАRIOT. In the same way, dependent on hair, nails, blood, and other aspects of material form, dependent on feeling, and on perception, and on conditioned volitions, and on consciousness, there is the concept NĀGASENA, "but in the ultimate sense there is no person to be found here" (Miln. 28).

Nāgasena holds that the concept of a person arises in a certain kind of dependence on mental and physical events, but it is not clear exactly how he conceives of this relation, since he denies that a person is (just) these mental and physical events. Thus it is not clear that Nāgasena and Parfit are advancing exactly the same position. There are, nonetheless, important similarities between the two. For Parfit, to hold a reductionist thesis about nations or persons is not to deny that either exist, but rather to deny that they are "separately, or independently, real." To hold a reductionist thesis about nations is to hold that the existence of nations "just involves the existence of citizens, living together in certain ways"; correspondingly, to hold a reductionist thesis about persons is to hold that existence of persons involves "nothing more than the occurrence of interrelated mental and physical events" (Parfit 1984: 340341). Nāgasena explicitly agrees with Parfit that a person is not something other than these mental and physical events. This is, of course, what makes both of them opposed to the metaphysical claim that the self is some substantial thing over and above interrelated mental and physical events; this far Nāgasena and Parfit are in 
agreement with the early Buddhist texts. For my purposes here, however, it is also important to notice a further parallel between these two theorists, in the perspective implicit in the analogies that they each adopt.

We look at a chariot and its parts from outside. There is no such thing as taking the chariot's perspective, imagining what it must be like for the chariot to ride over a rough surface or to be the king's own favorite vehicle. We do not perceive chariots as having an experiential perspective on the world. Similarly, when Parfit imagines a nation as constituted by its citizens and their relations, he seems to adopt a viewpoint that regards its citizens and their relations from above, as it were. The situation with persons is quite different. We can and do (if not always enough) relate to other people by imaginatively taking their perspective, imagining what it must be like to inhabit their experience of the world. Nāgasena and Parfit invite us to take up not the perspective of persons from the inside, but rather a perspective on persons from outside. By employing the analogies they offer, we regard pleasure and pain, perceptions and consciousness as objects in the world in the way that the parts of a chariot are objects in the world.

On my reading, the early Buddhist approach doctrine of nonself is not based on taking up such a perspective on experience from outside the world of experience. We can see this by turning back to the Anatta-lakkhana Sutta. The Buddha offers here an abridged argument for the conclusion that physical form, feeling, perception, conditioned volitions, and consciousness are not self:

If the body were self, bhikkhus, it would not bring affliction, and we would get [our wish] that the body be like this and not like that. But because the body is non-self, bhikkhus, it does bring affliction, and we don't get [our wish] that the body be like this and not like that. (SN III 66)

Martin Adam's (2010) presentation of the formal structure of the Buddha's argument here is instructive:

If there were a Self, he asserts, it would be that aspect of the person over which one has control. We do not have control over any of the five aggregates. The five aggregates are all that a person is. The implication is clear: there is no self. (Adam 2010: 246-247)

As Adam notes, the third premise in this argument-that the five aggregates are all that a person is-is both necessary for the argument to go through and is also not evident in the text. He assures us nonetheless that "this is a safe enough assumption from the Buddhist perspective" (Adam 2010: 247, n. 14). However, this is not a safe assumption. Gethin puts it well:

The five khandhas, as treated in the nikāyas and early abhidhamma, do not exactly take on the character of a formal theory of the nature of man. The concern is not so much the presentation of an analysis of man as object, but rather the understanding of the nature of conditioned existence from the point of view of the experiencing subject. Thus at the most general level rūpa, vedanā, sañ $\tilde{a} \bar{a}$, 
samkhāras, and viññana are presented as five aspects of an individual being's experience of the world. (Gethin 1986: 49)

Here, the point is not that early Buddhist sources see there being something to a person in addition to or apart from the khandhas. Rather the point is that the khandha analysis is not an analysis of what a person is, it does not take the person as its object nor as an object. It is instead an analysis of the lived experience of a subject, from within. For this reason it could not, in principle, tell us whether or not there is something to a person in addition to or apart from the khandhas. In order to determine that a chariot is nothing more than its parts in a certain kind of functional relation, we adopt a perspective on these parts from outside of them. Similarly, in order to determine that the khandhas are all that a person is, we would have to examine physical form, feeling, perception, conditioned volitions, and consciousness from outside of the person's subjective perspective.

However, the Anatta-lakkhana Sutta is not committed to adopting this external, objective perspective on a world of experience because it does not assert the idea that the five khandhas are all that a person is. Moreover, that premise is not necessary because the conclusion that Adam draws from that premise, that there is no self, is also not drawn in the discourse. Of course, Adam's reconstructed argument merely recapitulates a dominant understanding of the argument in the Anatta-lakkhana Sutta. Nonetheless, the fact that the final two out of the four steps in this dominant interpretation are not evident in the text should give us pause. Perhaps a better reading is available.

Recent work by Hamilton and Wynne goes a long way in this direction. Some scholars have argued that the Buddhist discourses fail to explicitly deny the existence of a self because these texts are instead implicitly committed to the existence of some subtle kind of self (for a recent example, see Albahari 2011). It is important to note, however, that denial and assertion are not the only two possible responses to the metaphysical question of whether there is a self. Neither asserting nor denying that there is a self, one can also reject the question, as the Buddha of the early discourses does with the set of metaphysical questions left unexplained (avyākata). ${ }^{10}$ Indeed, the Sabbāsava Sutta characterizes both the view that there is a self and also the view that there is no self as "a thicket of views" (MN I 8). Hamilton and Wynne each in effect offer a textual rationale for why, within an early Buddhist framework, the question of whether there is a self ought to be rejected. Both build on the insight noted above from Gethin, that the khandhas are offered as a kind of phenomenological analysis of human experience from within. And both come to the conclusion that the dominant understanding of early Buddhism as taking a reductionist stance toward the self misses the point of at least some central Nikāya discourses.

For Hamilton (2000: 129), "selfhood is neither the question nor in question." Instead, the essential project for the early Buddhist texts is to understand the cognitive processes that make possible the experience of objects in the external world. By understanding how we come to experience things in the world, we understand also the limits of what we can know through experience. In particular, "understanding dependent origination, in the sense that subjectivity and objectivity 
are mutually conditioned, one will no longer ask questions about existence" (Hamilton 2000: 184, emphasis in the original). The structures we perceive in the world, the parts of a chariot or the parts of human body, appear to us as objects existing in space and time independent of us because of the constructive nature of cognitive processes. But precisely because objects are constructed in this way through our subjective processes, it is not appropriate to ask about what reality these objects have independent of these subjective processes; that is beyond the limits of experience. For this reason, it is not appropriate to ask whether the self exists or not, as an object in the world; Hamilton points especially to the kinds of questions about existence of the self that are dismissed in the Paccaya Sutta (SN II 27), such as "am I?" and "am I not?" Here, and also more generally in the Pāli and other recensions of the early Buddhist discourses, personal insight into dependent co-arising is related to going beyond speculation about the self in the past and future (cf. Anālayo 2011: 253).

Wynne (2010) arrives at an interpretation very close to Hamilton's, referring to the approach he sees in the early Buddhist texts as doctrine of "epistemic conditioning." Although Wynne's textual argument draws on an array of sources from the Nikāyas, as well the larger Indic historical context, he says that "the most crucial evidence is provided by" the Mahānidāna Sutta, a portion of which is quoted in the epilogue above (Wynne 2010: 138). The central points of the Mahänidāna's critique are threefold, on Wynne's reading. First, it is possible to conceive of one's own existence when conditioned experiences arise; however, it is not appropriate to identify oneself with conditioned experiences, since these are changing. But, second, it is not appropriate to identify oneself as something apart from these experiences. It might be suggested that one can identify not with changing experiences, but with just the subjective sense of experiencing. Wynne shows convincingly the Mahänidāna targets just such a suggestion from the Chāndogya Upanisad. The Buddha rejects this suggestion on the grounds that when experience ceases entirely, it is not possible to conceive of one's own existence as an experiencing subject. For the same reason, however, it is not appropriate to identify with something apart from experiences and apart from the subjective sense of experiencing itself; it is not possible to have the notion "I am" (asmi ti) when there is no experience whatsoever (sabbaso vedayitam n' atthi). In brief, only within a world of experience are there the conditions "for being here to be conceived" at all, and every aspect within this conditioned world of experience is fleeting, and therefore inappropriate to identify with as self. If the argument goes through, there is no legitimate basis from which to assert the existence of a self.

On my reading, this line of early Buddhist thought is committed to rejecting any claim for the existence of a self. However, it is not committed to the assertion that there is no self. The move is instead to reject the question of whether there is a self, and therefore also all answers to that question, negative as well as positive. The central reason for this, brought out nicely by Hamilton and Wynne, is that on this early Buddhist approach one cannot assume that any objects exist independent of our experience of them. For this reason, the early Buddhist approach cannot be reconciled with reductive realism, the idea that persons do not ultimately exist, but 
are conditioned by, or constructed of, mental and physical processes that themselves do ultimately exist. By the same token, however, the approach equally cannot be reconciled with an (empirical) idealism that claims that the existence of objects consists only in their being experienced; the point is rather that to ask questions of what exists (or not) beyond our experience of them is to go beyond the conditions under which anything at all can be known. ${ }^{11}$

Early Buddhism does, of course, assume the sort of mundane knowledge of things and persons in the external world that we all have. However, the idea there could be some more ultimate perspective that sees how things in the external world are really constituted, while clearly present in some later Buddhist developments, seems much less evident in the early Buddhist discourses. Indeed, the early discourses do not use the term paramatthato to distinguish a class of things that exist in the external world (e.g., mental and physical processes) in a more ultimate sense than other things (e.g., persons). ${ }^{12}$ The Mahānidana claims that as long as there are the conditions for a world of experience, to this same extent there is also a path for concepts (pañnatti), a path for terms (vohāra), and scope for wisdom (pañ $\tilde{a})$. In contrast, Nāgasena seems to appeal to an ideal perspective that goes beyond concepts and yet still could give us knowledge of things in the world, and how they are constituted. Thus he claims that his name is merely a name (nāmamattam), a designation (sankhha), a

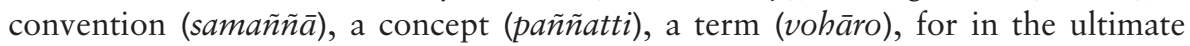
sense (paramatthato) there is no person to be found here.

We saw in the introduction to this chapter some evidence that the early discourses are committed to the notion of a type of wisdom that sees not only the arising of the world of experience, but also its cessation. Nothing about this, however, suggests that the discourses are committed a type of ideal perspective that sees how things in the external world are constituted on some ultimate level. I see little, if any, evidence that the early Buddhist discourses take such an ultimate perspective on things in the external world to be possible, much less that these discourses take such a perspective to be necessary in order to justify metaphysical claims. Even if they did, the discourses do not seem to draw inferences from the metaphysical claim that there is ultimately no self to ethical claims. And yet, clearly these same discourses are shot through and through with ethical claims, about how one ought to live, how one ought to act, and how one ought to cultivate one's mind. How are these claims to be justified?

\section{MINDFULNESS AND WISDOM}

It has been observed that despite the sophisticated developments of metaphysical and epistemological theory in various traditions of Buddhist philosophy, there is comparatively little in the way of the kind of ethical theorizing found in the Western tradition. Damein Keown has more recently argued that "although Buddhism has normative teachings, it does not have normative ethics" (2006: 50). He notes: 
The Five Precepts and the rules of the Vinaya ... are typically presented as injunctions, rather than as conclusions logically deduced from explicitly stated values and principles. In other words, the Precepts are simply announced, and one is left to figure out the invisible superstructure from which they are derived.

(Keown 2006: 50)

In response, Anālayo suggests that there is an identifiable principle underlying the Vinaya rules for monastics and more generally the ethical injunctions found in early Buddhist discourses. Based on a survey of sources from the Chinese Ägamas as well as from the Pāli Nikāyas, Anālayo suggests that "the early Buddhist counterpart to normative ethics-as distinct from applied ethics on the one hand and meta-ethics on the other-could be found precisely in the notion of purification of the mind from the influxes" (Anālayo 2012a: 83).

"Influx" here is a translation of the Pāli āsava, which Anālayo notes (2012b: 8112 ) is used in the sense of dangers, disturbances, and hardships that can "flow in" to the mind. By guarding the sense doors, eating and living moderately, as well as by purifying body, speech, and mind, more generally, one prevents unwholesome dhammas from flowing into the mind. In the pursuit of sense pleasures, the pleasures gained are mixed with the hardship and disturbances in the mind due to states such as lust. By purifying the mind through sense-restraint, in contrast, one "experiences internally an unmixed ease (sukha)" (as at MN I 181).

Anālayo's identification of the principle underlying early Buddhist ethical thought is, to my mind, precisely correct, so far as it goes. Nonetheless, a further question can be asked. Why is it that one ought to purify oneself of those states identified as āsavas by the early Buddhist teachings? Put another way, why is it that the wise purify their minds of these states and not other states? I think the answer is implicit already in the identification of āsavas as dangers and disturbances. We can experience for ourselves, internally, both the disturbance of unwholesome states and the unmixed ease of wholesome ones.

Here, the tight connection between the establishment of mindfulness (satipatthāna) and the development of wisdom (pañña) is crucial. I can only briefly summarize here an approach to this connection that I develop and defend in detail elsewhere (Davis 2014). According to the Vipallāsa Sutta, perceptions, thoughts, and views can be distorted (vipallāsa) (AN II 52). In the Māgandiya Sutta (MN I 501ff) and its parallel version in the Madhyama-agama, the Buddha illustrates this with an analogy: one with distorted perceptions due to leprosy might want to burn his flesh over hot coals, but on being cured he could not be induced to touch the coals by any means (Anālayo 2011: 410). In the same way, to those with perceptions distorted by craving, aversion, and delusion, the pursuit of sensual pleasure will appear enjoyable. But such distortions can be corrected. My suggestion, in brief, is that we establish mindfulness so as to gain a full and balanced awareness of all aspects of our experience of the world (cf. Anālayo 2014: 243), we purify ourselves of distorted perceptions (sañ $\tilde{n} \bar{a}$-vipallāsa), and thereby know and see our world of experience as it is. Feeling fully the holistic bodily, affective, mental, and perceptual 
aspects of being in states such as greed, hatred, or delusion, we just could not bear to encourage ourselves or others to cultivate such states-they simply involve too much internal agitation, disturbance, and hardship. Conversely, feeling fully the relative internal ease of states such as generosity, compassion, and clear seeing itself, we will naturally be moved to encourage others and ourselves to cultivate these states. In this way, I suggest, to the degree human beings from any cultural background develop a full and balanced awareness, their ethical judgments will tend to converge. In particular, to the degree individuals come to know and see as it is the experience of being motivated by various qualities of heart, they will converge in judging that we all ought to cultivate certain of these qualities and to purify ourselves of other qualities. On my reading, whatever degree of objectivity early Buddhist ethics aspires to, this objectivity is to be grounded in these judgments of the wise.

It will be noticed that this approach features a strongly Virtue Theoretic appeal to the judgments of the wise; nonetheless, two important points distinguish this early Buddhist approach from the approaches articulated by Aristotle and other Western virtue theorists. Aristotle's approach in the Nicomachean Ethics is sometimes charged with circularity, in that it simply appeals to the virtues generally accepted in his social environment without offering a justification for taking these character traits as the virtues. Philippa Foot (2003) attempts to adapt Aristotle's approach so as to underwrite a "species-wide notion of human good," by appealing to an objective, empirical conception of what counts as flourishing for a particular form of life. Suggesting that Foot's variety of naturalism is not Aristotle's, on the other hand, John McDowell (1998: 167ff.) instead seems to embrace an interpretation of Aristotle and an independent philosophical position on which there is no position from outside a cultural perspective from which to evaluate the relative merits of any picture of flourishing or of virtue. The early Buddhist approach helps to chart a path between these extremes, agreeing with McDowell that there is no view from nowhere from which to objectively determine flourishing or virtue, and yet insisting that a sufficient level of convergence in ethical judgment would emerge across human cultures, from the first-personal perspective, among individuals who develop mindfulness of their own emotional motivations for action.

One might challenge this contention by arguing that the perceptual experience of some states as internally disturbing and others as internally pleasurable will be culturally shaped, such that no amount of developing a full and balanced awareness would lead all human beings to agree on which states are wholesome and unwholesome. Indeed, one version of this worry can be developed in Buddhist terms, by pointing out that all the factors of the Eightfold Noble Path are required to develop the kind of full and balanced awareness that knows and sees the world of experience as it is. If so, perhaps, these eight factors form a holistic evaluative framework such that there is no way to specify independent of these other factors what it is to know and see the world of experience as it is, and so no reason to expect that individuals from different cultures, even to the degree they were knowing and seeing the world of experience as it is, would converge in their judgments of which qualities of heart are wholesome and unwholesome. And if so, then early Buddhism 
might be able to offer techniques (including the Eightfold Noble Path) to cultivate qualities of heart that some of us already agree ought to be cultivated, but it offers no novel reason for individuals from very different human cultures to agree that certain qualities of heart ought to be cultivated. Perhaps.

While we have seen above that some of the best evidence for reading the early Buddhist texts as Consequentialist comes from the Bähitika Sutta, the structure that Goodman finds in that discourse may be subject to a similar charge of circularity. We noted above that ethically normative terms, such as kusala, appear in the Bähitika Sutta (and its Chinese parallel) both as one of the terms being defined and in the final definition. ${ }^{13}$ Keown takes such points as counting against reading early Buddhist ethics as a form of Welfare-Consequentialism such as utilitarianism:

Unlike utilitarian theories Buddhism does not define the right independently from the good. There exists a clear conceptual relationship between the two, and they cannot be defined independently. (Keown 1992: 177)

Unfortunately, to the degree Keown is right in his reading of early Buddhist ethics, the framework may cease to be of interest to those who do not antecedently have faith in the Buddhist value framework as a whole.

A Consequentialist reading of Buddhist ethics might do better at providing an objective means for justifying a Buddhist framework of values over an Aristotelian one, say. This is precisely because a Consequentialist framework, if it is cogent, delivers an objective view of ethical reasons from outside any particular subjective or evaluative perspective on the world. In order to conceive of the amount of aggregate suffering in the world, and also in order to reduce persons to streams of mental and physical process, one abstracts away from any particular experience of the world, in order to adopt an objective perspective on experience itself. Nagel (1986: 162) describes this appeal to agent-neutral reasons as "the essence of traditional consequentialism." Consequentialism needs to appeal to reasons for action that are agent-neutral in the sense that they do not depend on occupying any particular experience of the world. In this sense, modern Consequentialist theories depend implicitly on a God's-eye perspective, what Nagel call's "the view from nowhere." And this is perhaps not surprising given that, as Julia Driver (2009) notes, Consequentialist theories of ethics arose in the West against the background of an explicitly theistic and monotheistic metaphysical framework. But this is not the background assumed in the early Buddhist texts.

Recall Goodman's suggestion above, that if we can locate in a system of thought a reductionist approach to persons, of the sort that would underwrite an agentneutral conception of ethical reasons, this can serve as evidence in favor of reading that system of thought as adopting a Consequentialist ethical framework. There is evidence for a reductionist approach to persons in later Theravāda texts such as the Milindapañha. However, the line of thought that Hamilton and Wynne reconstruct in the early Buddhist discourses is philosophically opposed to the sort of reductionism that Goodman appeals to, and so cannot offer support for a Consequentialist 
interpretation of early Buddhist ethics. But the implications for the Consequentialist reading of early Buddhist ethics are worse than just that.

The early Buddhist discourses reject and leave "unexplained" (avyākata) a set of metaphysical questions concerning whether the world is eternal or not, finite or not, whether the soul or life-faculty is different from the body or not, and whether a Buddha exists or not after death (cf. at MN I. 431 and its parallels, see Anālayo 2011: 353ff). As Hamilton points out, these questions presuppose that one can adopt a perspective on the world as an object independent of one's experience of it, and the existence of lives and bodies as objects in such a mind-independent world. On her reading, early Buddhism rejects this presupposition. According to Hamilton, if it is the case that

space and time are part of the structural characteristics of the experiential world, and that that is cognitively dependent, then one can see that the presupposition of the transcendental reality of time and space is false, and that the fundamental premises on which the questions rest are therefore also false. (Hamilton 2000: 174)

Note that in order to have a conception of what will maximize happiness or minimize suffering in the world, one must have a conception of the external world as finite. We have seen, for instance, that Goodman suggests how a Consequentialist theory focused on virtues will base its ethical judgments on the question of what increases "the total amount of virtue in the universe" (2009: 43). I suggested above that a Consequentialist theory taking occurrent states of mind as its primary focus of ethical evaluation would deliver many of the same ethical judgments that are found in the early Buddhist discourses; however, at a more fundamental level such an interpretation will need to appeal to some conception of the total good in the external world. Hamilton's analysis offers one principled explanation for why it is that the early Buddhist discourses do not make such an appeal.

There is a plausible alternative explanation that would appeal to pragmatic concerns rather than epistemic ones, arguing that the reason questions such as the whether the world is finite are not relevant to suffering and the end of suffering. But if so, then by implication a position in ethics that relies on the principle of there being a finite amount of suffering in a finite universe must also be rejected. In any case, whether for epistemic or pragmatic reasons, nowhere in the early Buddhist texts do we find formal procedure for weighing the total consequences in the external world of one action or one type of mental state against another, as finite and definite quantities, in order to make difficult ethical choices between, say, benefiting one set of individuals and benefiting another set of individuals. We noted above a number of discourses that do characterize unwholesome behavior as that leading to one's own affliction, to the affliction of others, or to the affliction of both. However, neither in these formulations nor elsewhere in these texts is a calculus proposed for deciding hard cases where we must weigh the suffering of one against the suffering of another, no suggestion that we ought to maximize total happiness or minimize total suffering conceived as a finite quantity in the universe. In short, 
there is abundant evidence in the early Buddhist ethics of suggestions that we ought to take consequences seriously, but vanishingly little evidence for Consequentialism as a principled approach to ethical decision-making.

The Consequentialist approach aims at a kind of objectivity that goes beyond what the early Buddhist discourses are committed to. On the other hand, I think it is clear that the early Buddhist approach is not simply aimed at offering a set of applied ethical principles for those who already endorse the Buddhist value framework. I cannot offer a comprehensive defense of this interpretive claim here (for a brief attempt, see Davis 2015). However, as a first pass, recall the passages from Kālāma Sutta and the Bähitika Sutta quoted in Section Two. These texts make ethical claims, about which actions and qualities of heart are wholesome and unwholesome, which are praiseworthy and blameworthy. These texts do not qualify their ethical claims as holding only within the circumscribed set of values held by some particular (sub) culture. The Buddha, as he is portrayed in the early discourses, is concerned to engage with individuals of many different convictions, for the purposes of changing their convictions such that they come to value cultivating certain qualities of heart and not others. There is no suggestion that he advocates his view about which qualities of heart others ought to cultivate just because it is his view, no better or worse than the views of others. The suggestion is instead, I take it, that individuals and whole cultures can be mistaken about what is praiseworthy and blameworthy, and indeed are mistaken just to the degree that the qualities of heart they praise and blame differ from what is praised and blamed by the wise ones, the Buddha first and foremost. Early Buddhism is, in this sense, committed at least to this minimal kind of objectivity. Whether the approach that it offers for achieving this minimal objectivity can deliver on that promise is a different question. I am optimistic about this, but for reasons I cannot defend in detail here (cf. Davis 2014).

Whereas Aristotle and some modern value frameworks might suggest that righteous anger is appropriate as a response to injustice; early Buddhism disagrees. On its own, this is not especially interesting; it is common that different individuals and different cultural groups hold opposing fundamental values. What is interesting is that the connection drawn between mindfulness and wisdom suggests a way in which the early Buddhist approach may offer a means that is independent of the Buddhist ethical framework to decide when it is that we as an individual or as a whole cultural group are wrong about which qualities of heart are wholesome. In a debate between Aristotelians and Buddhists, for instance, both sides can assess whether anger is, in fact, wholesome or unwholesome by appealing to the judgments that they themselves would make if they were aware in a full and balanced way of their own world of experience. If there is indeed some one judgment that both would converge on under such conditions, then this opens the possibility of a middle way in ethical justification. It avoids both the extreme insistence on absolute objectivity based on a "view from nowhere" and the insistence of the cultural relativist that there can be no justification of ethical claims outside a particular culture-bound evaluative framework. I see early Buddhist ethics as navigating a way between these extremes. 


\section{CONCLUSION}

The line of thought that I have brought out from the early Buddhist discourses emphasizes that in order to understand reasons and persons, one need not abstract away from one's experience of the world to regard experience objectively, as an object in the world in the way that we regard chariots and other dead matter. Rather, to the degree that one inhabits one's world of experience more fully, one knows and sees the nature of nonself and also the nature of what is wholesome.

Even if this line of thought is implicit in the early Buddhist discourses, it is not to be preferred to later Buddhist doctrines because it dates to an earlier period in Buddhist history. Wynne's historical argument that the Buddhist doctrine of epistemic conditioning predates Buddhist reductionism, for instance, is useful for my purposes here insofar as it suggests that the philosophical merits of these two different strands of thought can be considered separately. When we do that, we can see how grounding claims in ethics and metaphysics from within a world of experience proves a promising approach for moving forward contemporary philosophical debates.

This point has methodological implications for the study of non-Western philosophical sources. The approach to grounding ethical claims that I sketched in Section Four includes aspects that parallel a number of prominent theorists in Western moral philosophy, Kant as well as Hume, and Aristotle as well as Mill. ${ }^{14}$ However, the project of looking in Buddhist approaches for parallels within the familiar Western categories of philosophical theorizing downplays what is most radical, and therefore potentially most instructive, from a Western perspective. More fruitful, I think, is to investigate the ways in which the philosophical questions and the approaches to these questions that were developed in ancient India or China, for instance, might make their own distinctive contributions to contemporary debates that are already shaped by the important contributions of philosophers such as Aristotle, Hume, Kant, and Mill. ${ }^{15}$

Structuring our investigations in this way puts the burden on studies of ancient and foreign systems of thought to show that they have something important to teach us. This chapter has largely been focused on showing that what early Buddhist ethical thought has to teach is not (just) what Aristotle or Parfit have already taught us. There is much more to be said about how the early Buddhist line of thought emphasizing epistemic conditions on the world of experience can move forward contemporary debates on the nature of persons and the nature of reasons. Nonetheless, the general shape of the novel contribution that early Buddhist ethics can make should be clear.

From within a world of experience, we see particular beings as suffering. If we are in wholesome states rather than unwholesome ones, we respond appropriately to their suffering. But this is not because we regard suffering as existing on its own as an object in the external world, in the way that we regard parts of chariots and other dead matter. We can express compassion as a concern for all beings, and even cultivate that state by employing such a notion. Nonetheless, this does not suggest that one must employ a conception of the limits of the universe and the total 
aggregate consequences of each action in order to decide how to act, live, or be. Rather, one ought to care about how her actions affect her own and others' welfare in virtue of the fact that the qualities of heart that would lead her to care in this way, such as compassion, are qualities of heart that ought to be cultivated. And this is a fact that one can discover within, and only within, one's own world of experience.

Throughout the Nikāyas, the Buddha's teachings are characterized as experiential, timeless, a come-and-see kind of thing, progressive, to be experienced by the wise for themselves (paccattam veditabbo viññühi). On my reading, this last phrase offers a particularly helpful key to a better understanding of the ways in which early Buddhist thought on reasons and persons aspires to objectivity, and the ways in which it does not. The distinctive contribution of early Buddhist ethics is to suggest that we each can become wise, coming in this way to know and see for ourselves, from within our own experience of the world, which qualities of heart are praised and criticized by the wise.

\section{NOTES}

1. References to the Pāli are to Dīgha (DN), Majjhima (MN), Samyutta (SN), or Añguttara Nikāyas (AN), Milindapañha (Miln.), and Vinaya (Vin.), followed by volume and page numbers of the Pali Text Society edition. Translations are my own except where otherwise noted.

2. This chapter has benefitted greatly from conversations with Martin Adam, Bhikkhu Anālayo, Georges Dreyfus, Laura Guerrero, Stephen Harris, and Alexander Wynne. I am very grateful for their suggestions and critiques; the remaining errors are, of course, my own.

3. For reasons of space, I focus here on Keown's and Goodman's influential analyses of Buddhist ethics. In the course of his insightful book on Buddhist reductionism and Buddhist anti-realism, Siderits (2003) also offers a Consequentialist reconstruction of Buddhist ethics.

4. These qualities of heart are referred to in the Kālāma Sutta negatively, as nongreed (alobha), non-aversion (adosa), and non-delusion (amoha). Maria Heim refers to this feature of early Buddhist thought as "the presence of absences" and argues convincingly that this is "an important feature of this moral psychology that identifies experience of absence as the conditions for other experience that cannot otherwise occur" (Heim 2014: 79).

5. Ranganathan in "Moral Philosophy: The Right and the Good" (chapter 1 of this book) argues that all instances of dharma/dhamma be translated with ethical terms. In the case of a use of dhamma as a plural noun, as here in the discourse with Kālāmas, this approach would gloss something like "ethicals" or "ethical states," to be cashed out as elements (states, traits, acts, etc.) "that would fall within the ideal ethical theory" or "within the ideal theory of the right and the good". And dhammata, which I translate below as "the nature of things" (as in the case of a certain causal progression of psychological states), would instead be translated as 
"the virtue of things." I take it that this approach of Ranganathan's is intended as a corrective measure, in the face of allegations that Indian philosophy has lacked ethical theorizing (in contrast to metaphysical and epistemological varieties). Indian philosophers certainly have plenty of theories about dharma and about dharmas, so if we do take "dharma" as connoting the subjects of debates about the ideal ethical theory, then it is clear that India has not lacked in ethical theory! A central point of my chapter is that we could render my point as being that certain of the elements that would figure in the ideal philosophical theory, namely, occurrent states such as greed and compassion, are claimed by the early Buddhist discourses to be the elements that would figure in the ideal ethical theory. On this approach, we might better translate all instances of dharma/dhamma with instances of "philosophy." Adopting Wilfrid Sellar's (1962) characterization or philosophy, we could then say that dharma is concerned with "how things in the broadest possible sense of the term hang together in the broadest possible sense of the term." On this approach, dharmas (in the plural) are the things that hang together, being the elements that fall within the realm of philosophical debate (and not just the subset of that which is ethical). Of course, Sellar's is but one stance within a debate about the nature of dharma/philosophy, and the early Buddhist take might well be another.

6. Gethin (2004: 185) quotes a recollection from Ajahn Buddhadassa's attitude toward death; for a closely parallel account in the Burmese tradition, see Mahasi Sayadaw (1992: 80-81).

7. This being a philosophical term of art, it is worth noting that Hallisey's use of "particularism" (borrowed from Chisholm) has affinities to, if also some differences from, Dancy's use of the term "particularism” within philosophical ethics. Dancy uses "particularism" to name the conclusion that "there is nothing for ... moral principles to do" (this following from his "holistic" view of practical as well as theoretical reasons), and that "people are quite capable of judging how to behave case by case, in a way ... which shows no need of the sort of explicit guidance that a set of principles (of a certain sort) would provide" (Dancy 2004: 82-83).

8. Adams's (1976) "motive utilitarianism" offers an example of a similar approach in the Western literature, though not an influential one.

9. I take it Goodman reads Ānanda as giving intensional definitions, as making a claim about what it is in virtue of which a state is blameworthy, e.g., rather than merely claiming that those states that are blameworthy and those states that bring affliction are coextensive. The phrasing of the dialogue, if not the structure, is ambiguous between the two.

10. I discuss these briefly below.

11. Hamilton rightly identifies this approach she sees in early Buddhism as a kind of "transcendental idealism" akin to Kant's. I cannot take up in any detail here the interesting question of to what degree this approach also resembles that adopted by the Pudgalavādins. While they do seem to have reached some of the same conclusions (viz., that the Buddha's claim is not that there is no self), the reading 
of the Nikāyas espoused by Hamilton and Wynne depends on the idea that we should reject the question of whether there is a self because to ask questions of what exists (or not) beyond our experience of them is to go beyond the conditions under which anything at all can be known. It is not clear that this same reasoning lay behind the Pudgalavādin interpretation.

12. The poem by the nun Vajirā does speak of there being the convention (sammuti) of "a being" (satto), when the aggregates are present (khandesu santesu). But it is less clear that this underwrites the sort of distinction between ultimate and conventional that Nāgasena appeals to. Wynne (2010) argues, controversially, that this poem represents a significant stage in the historical progression toward the reductive realism evident in Nāgasena's formulation, for it speaks of the khandhas as existing things, among which "no being is found" (nayidha sattūpalabbhati).

If the poem does depend on the notion of an ultimate perspective on how things are constituted in the world, as opposed to how they appear conventionally, then perhaps Wynne is correct about the philosophical point. However, according to the argument noted above from Anālayo (2012a), if there is an answer to the historical question of whether the poem is to count as belonging to early Buddhist thought, this would be best to assess from a comparative perspective.

13 Moreover, the actions initially identified as unwholesome, for which later definitions are offered, are just those actions that would be criticized by people who are wise; this is a point brought out with special force in the Chinese parallel to the Bāhitika Sutta, and in the Burmese and Ceylonese versions of the Pāli discourse (Anālayo 2007: 173, n. 15).

14 I have not addressed the former two in this chapter; for more on similarities to and differences from Kant, Hume, Aristotle, and Mill, as well as contemporary theorists of ethics and metaethics, see Davis (2014).

15 In this I echo a number of recent scholars of Buddhist ethics (Hallisey 1996; Heim 2014; Garfield in press) including Keown himself (2006), and in a recent conference presentation talk (Contemporary Perspectives on Buddhist Ethics, Columbia University, October 6, 2011).

\section{BIBLIOGRAPHY}

Adam, M. "No Self, No Free Will, No Problem: Implications of the Anattalakkhana Sutta for a Perennial Philosophical Issue." Journal of the International Association of Buddhist Studies 33, no. 1-2 (2010): 239-265.

Adams, R. M. "Motive Utilitarianism.” The Journal of Philosophy 73, no. 14 (1976): 467-481.

Albahari, M. 2011. "Nirvana and Ownerless Consciousness." In Self, No Self?, edited by M. Siderits, E. Thompson, and D. Zahavi, 79-114, Vol. 1. New York: Oxford University Press. 
Anālayo, Bhikkhu. "What the Buddha Would Not Do, According to the Bāhitika-sutta and Its Madhyama-āgama Parallel.” Journal of Buddhist Ethics 14 (2007): 153-179.

Anālayo, Bhikkhu. 2011. A Comparative Study of the Majjhima-nikāya. Taipei, Taiwan: Dharma Drum.

Anālayo, Bhikkhu. “The Historical Value of the Pāli Discourses.” Indo-Iranian Journal 55 (2012a): 223-253.

Anālayo, Bhikkhu. "Purification in Early Buddhist Discourse and Buddhist Ethics." Buddhist Studies (Bukkyō Kenkyū) XL (2012b): 67-97.

Anālayo, Bhikkhu. 2014. Perspectives on Satipaț̣ana. Cambridge: Windhorse.

Bodhi, B. 2000. The Connected Discourses of the Buddha: A Translation of the Samyutta Nikāya. Translated by B. Bodhi. Boston, MA: Wisdom.

Dancy, Jonathan. 2004. Ethics without Principles. Oxford: Clarendon Press.

Davis, J. H. 2014. Acting Wide Awake: Attention and the Ethics of Emotion. New York: City University of New York Graduate Center.

Davis, J. H. "Review of The Forerunner of All Things: Buddhaghosa on Mind, Intention, and Agency by Maria Heim." International Journal for Philosophy of Religion 77, no. 3 (2015): 261-266.

Driver, J. 2009. The History of Utilitarianism. Stanford Encyclopedia of Philosophy. http://plato.stanford.edu/archives/sum2009/entries/utilitarianism-history/; accessed Winter 2015.

Foot, P. 2003. Natural Goodness. Oxford: Oxford University Press, USA.

Garfield, J. L. (In press). “Buddhist Ethics.” http://www.smith.edu/philosophy/docs/ garfield_buddhist_ethics.pdf; accessed Winter 2015.

Gethin, R. "The Five Khandas: Their Treatment in the Nikāyas and Early Abhidhamma." Journal of Indian Philosophy 14 (1986): 35-53.

Gethin, R. "Can Killing a Living Being Ever Be an Act of Compassion? The Analysis of the Act of Killing in the Abhidhamma and Pali Commentaries." Journal of Buddhist Ethics (2004): 167-202.

Gombrich, R. F. 2006. How Buddhism Began: The Conditioned Genesis of the Early Teachings. New York: Routledge.

Goodman, Charles. 2009. Consequences of Compassion: An Interpretation and Defense of Buddhist Ethics. Oxford: Oxford University Press.

Hallisey, C. "Ethical Particularism in Theravāda Buddhism." Journal of Buddhist Ethics 3 (1996): 32-43.

Hamilton, S. 2000. Early Buddhism: A New Approach-The I of the Beholder. Richmond, Surrey: Curzon Press.

Heim, M. 2014. The Forerunner of All Things: Buddhaghosa on Mind, Intention, and Agency. New York: Oxford University Press.

Keown, D. 1992. The Nature of Buddhist Ethics. New York: Palgrave.

Keown, D. 2006. "Buddhism: Morality without Ethics?" In Buddhist Studies from India to America: Essays in Honor of Charles S. Prebish, edited by D. Keown, 45-55.

London: Routledge.

McDowell, J. H. 1998. Mind, Value, and Reality. Cambridge: Harvard University Press. Nagel, Thomas. 1986. The View From Nowhere. New York: Oxford University Press. 
Parfit, Derek. 1984. Reasons and Persons. Oxford, Oxfordshire: Clarendon Press.

Sayadaw, Mahasi. 1992. Questions about Life [In Burmese] (Bhava Pyathana). Yangon, Myanmar: Buddha Sasana Nuggaha Organization.

Sellars, Wilfrid. 1962. Philosophy and the Scientific Image of Man: Frontiers of Science and Philosophy, edited by Robert Colodny. Pittsburgh, PA: University of Pittsburgh Press.

Siderits, M. 2003. Personal Identity and Buddhist Philosophy: Empty Persons. Burlington, VT: Ashgate.

Singer, Peter. "Famine, Affluence and Morality." Philosophy and Public Affairs 1, no. 3 (1972): 229-243.

Wynne, A. "The Ātman and Its Negation: A Conceptual and Chronological Analysis of Early Buddhist Thought." Journal of the International Association of Buddhist Studies 33 (2010): 103-171. 
